\title{
NEW CULTIVARS
}

Keywords: cultivar: Sarracenia 'Waccamaw', Sarracenia flava var. rugelii 'Bob Hanrahan'

Submitted: 25 April 2013

\author{
Sarracenia 'Waccamaw'
}

This exceptional clone of Sarracenia flava var. atropurpurea is a superb representative of the uncommon variety native to the Green Swamp of North Carolina, USA. The clone was originally imported to New Zealand as vegetative material by the Christchurch Botanical Gardens circa 1980. It was subsequently obtained by me in 1987. It has been maintained solely via vegetative propagation since that time in order to preserve its distinctive properties.

Representative of the form of $S$. flava varieties native to the east coast of the species range, a strong flush of pitchers follows typical $S$. flava flowers produced during early spring. The clone readily produces rhizome divisions with two or three pitchers emergent from each rhizome growth point. Phyllodia, typical S. flava in form, are produced during late autumn and endure through winter.

The pitchers attain a height of $60-80 \mathrm{~cm}$. From the outset of pitcher growth, under optimal conditions of maximum possible sunshine, exterior coloration is a uniform bright red throughout the length of the pitcher including the outer hood (Fig. 1). It is noteworthy by contrast that once the pitcher opens, the nectar roll, the interior of the pitcher, the column, and the underside of the hood are bright yellow. Superimposed on the bright yellow interior surface is a network of bright red veining. A feature of the column is a prominent central red vertical stripe. Accompanying the red stripe are red veins that follow from the interior of the pitcher rising upward through the column branching out into the surface of the underside of the hood (Fig. 2 ). The outer margin of the hood is without undulations. As the growing season progresses, by mid-summer the bright yellow surfaces become infused with a varying degree of red. Autumn phyllodia also attain a reddish coloration under optimal light conditions. This sum of features reflects those recorded in the wild (Schnell 1998; Fowler 2008a,b).

The name 'Waccamaw' is in reference to Lake Waccamaw which is within the confines of the Green Swamp, North Carolina, being the native habitat of the Sarracenia flava var. atropurpurea.

Vegetative propagation is necessary to maintain the unique features of this cultivar.

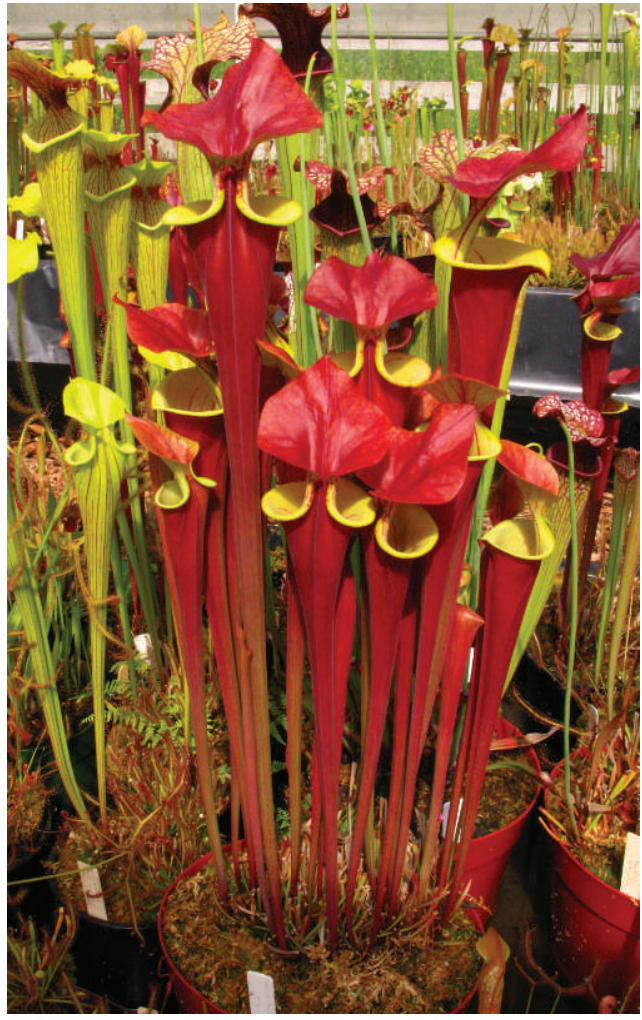

Figure 1: Sarracenia 'Waccamaw' plant. Photo by Julian D. Brook. 

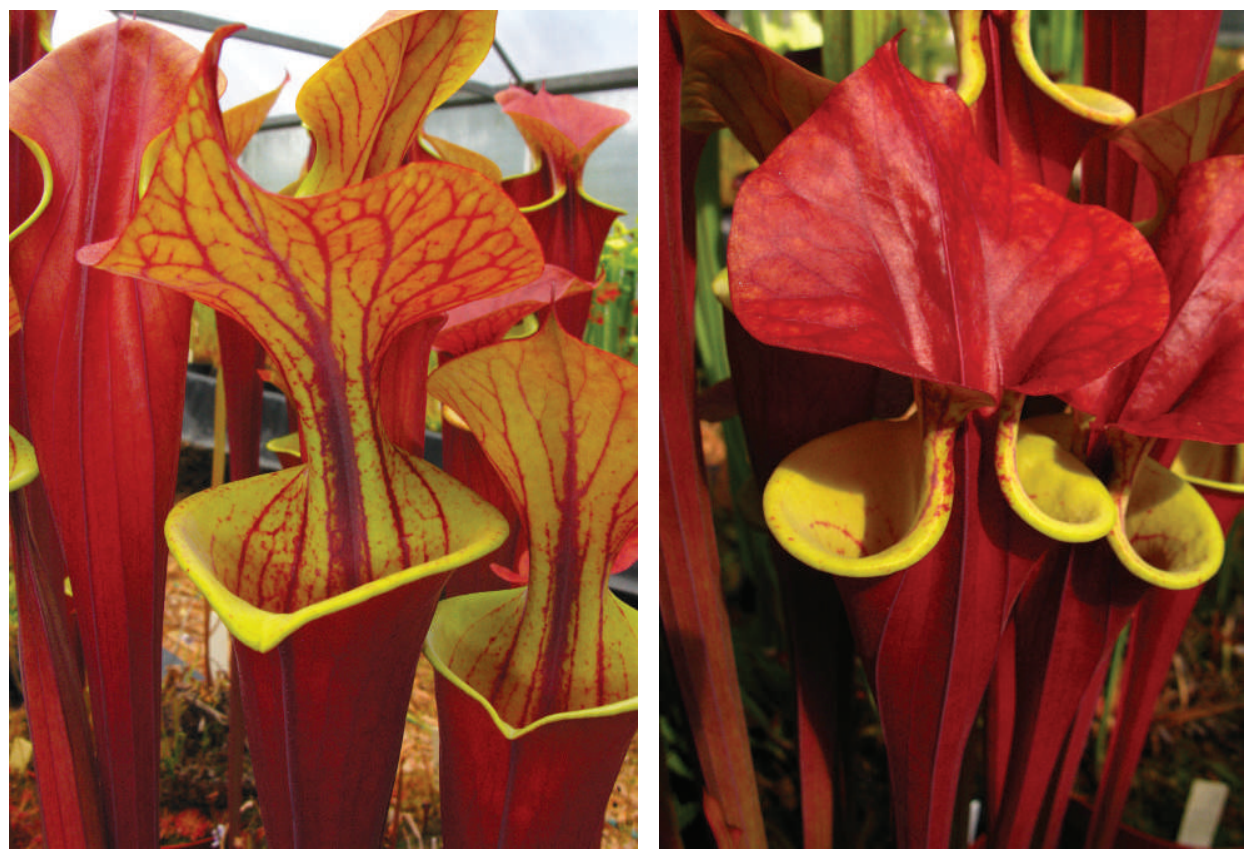

Figure 2: Sarracenia 'Waccamaw' front (left) and rear views (right). Photos by Julian D. Brook.

\section{References}

Schnell, D. 1998. Sarracenia flava L. varieties. Carniv. Pl. Newslett. 27(4): 116-120.

Fowler, J. 2008a. Green Swamp Orchids and Carnivorous Plants. http://www.pbase.com/ jimfowler/20080511greenswamp, accessed 28 April 2013.

Fowler, J. 2008b. Day trip to the Green Swamp, North Carolina. http://www.pbase.com/ jimfowler/20080504greenswamp, accessed 28 April 2013.

—DON GRAY • Auckland • New Zealand・don.gray@xtra.co.nz

\section{Sarracenia flava var. rugelii 'Bob Hanrahan'}

Submitted: 12 June 2013

In the early 1990's, Peter received what looked like a typical Sarracenia flava var. rugelii from Bob Hanrahan. As it grew in the collection at California Carnivores, it became quite evident that there was nothing typical about this plant. Damon remembers as a boy noticing it in the collection and remarking to Peter about its striking beauty and size (Fig. 3).

It's a nice tall clone, growing up to $80 \mathrm{~cm}$ tall. We have a few $S$. flava's that grow a bit taller, but none that are as elegant as this one. The tall pitchers are a yellow-green so bright that they seem to glow in the vernal sunlight as they emerge. The only splash of red is a solid patch in the throat, typical of the rugelii variety. Perfectly grown plants may also have a thin red picotee along the front edge of the lid. The mouth of the pitcher flares wide like a trumpet and the lip has a deep cleft in the front, which also adds to its regal appearance. 

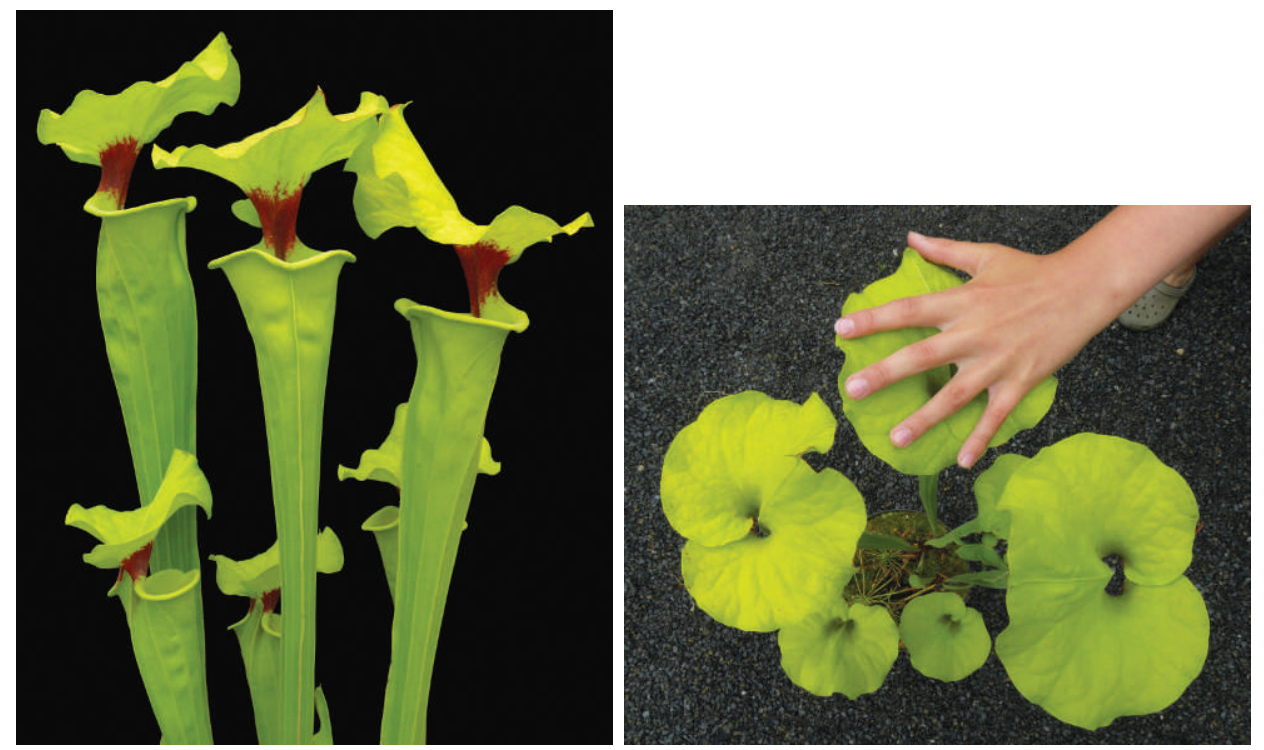

Figure 3: Sarracenia flava var. rugelii 'Bob Hanrahan' pitchers and lid. The hand of young CP grower David Green for scale.

It is the ridiculously huge lid, however, that really sets this clone apart. The large mature pitchers have an undulating lid that can be just over $15 \mathrm{~cm}$ across! There's a childlike joy you get from putting your hand atop the pitchers and seeing it fit nicely across the gigantic lid (Fig. 3). It has a simple and classic beauty reminiscent of the modern columns designed by Frank Lloyd Wright, which seem too tall and top heavy to stand. Peter and Damon both agree that it is the most perfect $S$. flava var. rugelii that we have ever grown or seen. It produces only a few pitchers per growth point, probably due to the high energy costs of producing pitchers so large and spectacular. The flowers are typical of $S$. flava with long yellow petals.

It is with much love and respect that we name this plant in honor of our friend Bob Hanrahan. He gave so much to California Carnivores in the early days and to the hobby of growing carnivorous plants in general; we might not even be here today if it weren't for his generosity and enthusiasm over the years. When we heard of his passing, we knew that we would have to name one of the very best plants in our collection for him. This seems a fitting choice, as it has long been one of our alltime favorite plants and its tall, stately pitchers remind us of Bob himself.

Previously, this plant has been labeled as Sarracenia flava var. rugelii "Big Lid", however, this old name shall no longer be used hereafter.

We are in the process of establishing this clone into tissue culture, so that everyone may have the pleasure of growing this wonderful plant. True Sarracenia 'Bob Hanrahan' should only be vegetatively propagated. Seeds obtained by selfing or out-crossing will probably not be true.

-Damon Collingsworth • Peter D’Amato • California Carnivores • 2833 Old Gravenstein Hwy

- Sebastopol, CA 95472•califcarn@aol.com 